\title{
Technology Acceptance Model (TAM): Measurement of E-Learning Used By Accounting Students of State University of Malang
}

\author{
Abdul Khafit ${ }^{1,}$ Sulastri ${ }^{2,}$ Miranti Puspaningtyas ${ }^{3 *}$ \\ ${ }^{1,2,3}$ Faculty of economic, State University of Malang \\ *Correspondence author. E-mail: miranti.puspaningtyas.fe@um.ac.id
}

\begin{abstract}
Based on the Technology Acceptance Model (TAM) theory, the use of e-learning influenced by usefulness perception, and ease of use perception by adding other factors, namely self-confidence and subjective norms. This study aims to determine: (1) The effect of usefulness perception on the use of e-learning; (2) The effect of ease of use perception on e-learning; (3) The effect of self-confidence on the use of e-learning; (4) The effect of subjective norms on the use of e-learning. The explanation approach is used to explore the data in this study. The population in this study was 116 students of accounting education bachelor program in 2016 period. The number of samples in this study were 116 students. Collecting data in this study used a questionnaire with a Likert scale as a measure of research variables. Analysis of the data used is multiple linear regression. The results of this study indicate that usefulness perception, ease of use perception, self-confidence, and subjective norms have a significant effect on the use of e-learning.
\end{abstract}

Keywords: TAM, Perception, Use of E-learning

\section{INTRODUCTION}

The use of information technology (IT) is inseparable from everyday life for teachers and students in the teaching and learning process, especially the internet. The abundance of information provided is a special attraction for its users, especially students in finding various information or solving problems in learning assignments. This makes new discoveries in the world of internet-based education, one of which is elearning. E-learning is a medium for the distance learning process that can be used as a supporting tool for the teaching and learning process and can cover several problems such as time and distance (Firmansya \& Mehendra, 2004).

According to Pawellangi (2009) e-learning is a learning medium that allows students to access materials any time. The use of moodle e-learning is intended to develop increased learning flexibility. Students who use e-learning can access learning materials any time and repeatedly. In such a condition, it can further strengthen the mastery of the learning subject by students.

Apart from the advantages mentioned above, the elearning system will not function optimally if students do not understand well in using the system. The key to the successful use of e-learning can be seen from the level of acceptance and use by students (Raaij \& Schepers, 2008). Students as users can use e-learning to engage and participate in the learning process. The low intensity of e-learning usage by students indicates a problem with elearning acceptance. This problem becomes important for practitioners and policy makers to understand the main factors that influence the use of e-learning systems to improve the learning experience of students.

Evaluating students' interest in using e-learning is very important for the success and sustainability of its use by students, lecturers, and universities. Several models have been used to explain users interest in using technology. One model is Technology Acceptance Model (TAM), which was proposed by Davis (1985). TAM is a model that has often been used to explain the acceptance of a technology. In the TAM model, there are two factors that can influence technology acceptance, namely usefulness perception and ease of use perception (Davis, 1985 in Aristian, et al. 2016).

In addition to the factors contained in TAM, factors from within and outside the individual can also influence actions in using e-learning. In this study, 
the variables of self-confidence and subjective norms are added. This study took the research subjects of students of the S1 Accounting Education study program, State University of Malang. Therefore, this study aims to examine whether there is an effect of usefulness perception, ease of use perception, self-confidence and subjective norms on the use of e-learning by students of accounting education.

The usefulness perception is the extent to which a person believes that using a particular technology will improve their performance (Davis in Aristian, et al. 2016). Based on this understanding, it can be interpreted that using e-learning can improve users' performance and they will take an advantage of elearning if it is useful in their work. Jogiyanto (2007, p. 114) explained that usefulness perception is the most significant construct and can influence attitude, behavioral intention, and behavior in using technology than other constructs. Based on this, usefulness perception is one of the factors that can influence the use of e-learning

The ease-of-use perception is the extent to which a person believes that using a certain technology will be independent from an effort (Davis in Aristian, et al., 2016). Ease of use of e-learning is also a factor that can influence users to access e-learning. Venkatesh and Morris (2000) stated that ease of use perception has an impact on behavioral interest (intention). The easier e-learning to be used, the easier to increase the use of e-learning by users.

Ali Tarhini, et. al (2017) conducted a similar research before by using Structural Equation Modeling Approach (SEM) analysis. Samples of data from two universities in England with data collection using a cross-sectional in his research found that usefulness perception is proven to affect the use of e-learning and ease of use perception also affect the use of e-learning. Other researches also conducted by Richard Boateng, et al by using the Technology Acceptance Model (TAM) with Structural Equation Modeling Approach (SEM) analysis. The data sample from 337 respondents at Ghana University obtained the results of usefulness perception which was proven affecting the use of elearning, while the ease of use perception was not proven affecting the use of e-learning.

Another research conducted by Michael, et al (2016) at Atma Jaya Yogyakarta University. As many as 293 students as respondents with the multiple regression method, it was found that the usefulness perception was proven affecting the use of elearning, while the ease of use perception was not proven affecting the use of e-learning. Based on several previous studies that have been carried out using the TAM technology acceptance model on the use of e-learning, different results are obtained among studies. Therefore, this study aims to test the applicability of the TAM model consisting of the influence of usefulness perception and ease of use perception. The level of use of e-learning technology carried out by students of State University of Malang is by adding intrinsic and extrinsic factors. These factors include self-efficacy and subjective norms.

State University of Malang (UM) is one of the universities which has a direct mandate from the government to develop sustainable the world of education and give an innovation to support the quality of curriculum and learning in Indonesia. Several innovations have been carried out by UM, one of which is the online learning system (SIPEJAR) by using e-learning to support face-toface and online lectures. In supporting this strategy, UM has added wifi facilities throughout the campus area with a bandwidth of 2400 mbps. After this implementation, there is a need for an evaluation and consideration for future development, that it can provide an effective way.

The theoretical framework in this study uses the theory of Davis (1989), namely the Technology Acceptance Model (TAM), explaining the acceptance of an information system consisting of usefulness perception and ease of use perception. This study adds another factor, namely selfconfidence and subjective norms.

\subsection{The Effect of Usability Perceptions on the Use of E-learning in Accounting Students}

Usability perception is one of the factors of the Technology Acceptance Model (TAM) theory proposed by Davis. Usefulness perception is related to the acceptance of an information system. David (1989) explained that usefulness perception has a stronger and more consistent relationship with information systems. The usefulness perception in this study is an assumption about how far e-learning can be useful for users. By this utility, it can also be interpreted that the system provides meaningful use for its users and the use of e-learning system is not useless. The benefits obtained from the use of elearning are the effectiveness in learning, support learning. It can provide value-added to e-learning system which can make someone use e-learning. The more benefits that are obtained from the use of e-learning by users, the more students use elearning. Thus, the hypothesis in this study formulated: 
H1: Usability perception has a significant effect on the use of e-learning.

\subsection{The Effect of Perceptions of Ease of Use on the Use of E-learning in Accounting Students}

Another factor of Technology Acceptance Model (TAM) theory is ease of use perception. The of use perception is a person's level of ease with regard to the use of information systems. Jogiyanto (2007) stated that if a system can be used easily, the effort required is not too high and vice versa. Ease of use of e-learning system will reduce an effort, both in one's time and energy in studying and doing assignments. Ease gives an indication that someone who uses technology works more easily than someone who works manually. The use of e-learning makes people easier in learning because it is more easily accessible by via mobile for 24 hours. Thus, the hypothesis formulated in this study is:

$\mathrm{H} 2$ : The ease of use perception has a significant effect on the use of e-learning

\subsection{The Effect of Self-Confidence on the Use of E-learning in Accounting Students}

In the context of information systems, selfconfidence is defined as an individual's ability to use computer systems to fulfill tasks. An individual who feels that the ability to use computerization is high tends to use it more often for things that are considered to be done with the computer. Selfconfidence is the most important predictor that directly affects the use of information systems (Yunasti, Ika \& Baridwan, 2013). Students with high self-confidence will feel confident in their competence so that they can use e-learning for learning needs and doing assignments and can achieve expected results such as high scores. Likewise, students with a low self-confidence feel less confident about their competence in using elearning for learning needs or doing assignments and these students tend to not use the technology. Thus, the hypothesis formulated in this study is:

H3: Self-confidence has a significant effect on the use of e-learning.

\subsection{The Effect of Subjective Norms on the Use of E-learning in Accounting Students}

Subjective norms are one of the factors in Ajzen's theory of planned behavior. Subjective norm is a situation where there is social influence to do or do not do something. A person does not fully perform or does not carry out a behavior or action is purely formed in oneself but is impulse obtained from outside oneself. This subjective norm is one of the conceptual effects of the environment. For students, the closest people who can be influential in using or not using e-learning are lecturers and friends. In this case, the greater the encouragement that students receive in using the e-learning system, the more likely users are to use e-learning. Thus, the hypothesis formulated in this study is;

H4: Subjective norms have a significant effect on the use of e-learning.

\section{RESEARCH METHOD}

This study used quantitative explanation method, which aims to explain and provide reasons for the cause of a phenomenon and based on a theory or hypothesis (Wijaya, 2013, p. 2). The population used in this study were all students of the S1 Accounting Education study program, State University of Malang, in 2016, 2017 and 2018 period. The sampling technique used was Simple Random Sampling. To obtain the necessary data, researchers used a questionnaire distributed to 194 respondents, consisting of 53 male students and 141 female students.

The research instrument used to obtain data in this study is questionnaire. The form of statements in the questionnaire in this study is structured questionanswer or called a closed direct questionnaire and the type of positive questions. The scale used in the questionnaire is an ordinal or Likert scale. The Likert scale according to Sekaran $(2015$, p. 31) is used to examine subjects agree or disagree with statements on a 5 point scale, namely strongly disagree (1), disagree (2), disagree (3), agree (4), strongly agree (5).

The type of data used in this study is quantitative data, namely data or information expressed in numerical units, discrete (wholly), or continuous (fraction / interval) (Wijaya, 2013, p. 20). The quantitative data that is considered in this study is data obtained from the results of a questionnaire to measure the usefulness perception variables, ease of 
use perception, self-confidence, subjective norms, and the use of E-learning that has been distributed to respondents. This study used four independent variables, namely usefulness perception (X1), ease of use perception (X2), self-confidence (X3), subjective norms (X4), and the dependent variable using e-learning (Y). The population in this study were all students of Accounting Education study program in 2017-2018 period, State University of Malang with a total of 116 students, and a sample of 116 students.

\section{RESULT}

All instruments used in this study must go through the instrument test stage first. The results of the validity test show that all statement items for each variable are valid. Meanwhile, the results of the reliability test of each variable are reliability pressure of 0.734 ; opportunity reliability of 0.883 ; rationalization reliability of 0.827 ; and the reliability of academic cheating behavior is 0.873 . Hypothesis testing in this study was carried out using multiple linear analysis. Priyatno $(2009$, p. 137) stated that this analysis is useful for analyzing the linear relationship between two or more independent variables with one dependent variable. The following is the result of multiple linear regression analysis.

Table 1. Multiple Linear Regression Analysis Test Results

\begin{tabular}{|c|c|c|c|c|c|}
\hline \multirow[t]{2}{*}{ Model } & \multicolumn{2}{|c|}{ Unstandardized Coefficients } & \multirow{2}{*}{\begin{tabular}{|r}
$\begin{array}{l}\text { Standardized } \\
\text { Coefficients }\end{array}$ \\
Beta
\end{tabular}} & \multirow[t]{2}{*}{$\mathrm{t}$} & \multirow[t]{2}{*}{ Sig } \\
\hline & B & Std. Error & & & \\
\hline (Constant) & 1,018 & 1,290 & & .789 & .432 \\
\hline PERCEPTION_USA & .362 & .082 & .377 & 4,435 & .000 \\
\hline EASE_OF_USE_PERCEPTION & .214 & .088 & .205 & 2,440 & .016 \\
\hline SELF CONFIDENCE & .219 & .097 & .181 & 2,264 & .026 \\
\hline NORMA_SUBYECTIVE & .143 & .069 & .176 & 2,072 & .041 \\
\hline
\end{tabular}

Source: Attachment of t Test Results

Based on the data above, it can be concluded that the constant value is 0.955 , meaning that if the usefulness perception, ease of use perception, selfconfidence, and subjective norms are zero (0), then the use of e-learning is 0.955 . The coefficient value of the usefulness perception variable is 0.343 , meaning that if the perceived usefulness increases by 1 unit, the use of e-learning will be increased by 0.343 , assuming other independent variables have a fixed value. The coefficient value of the ease of use perception variable is 0.143 , meaning that if the ease of use perception increased by 1 unit, the use of elearning will be increased by 0.143 assuming other independent variables have a fixed value.

The coefficient value of the self confidence variable is 0.356 , meaning that if self-confidence has increased by 1 unit, the use of e-learning will be increased by 0.356 assuming other independent variables have a fixed value. The coefficient value of the subjective norm variable is 0.137 , meaning that if the subjective norm is increased by 1 unit, the use of e-learning will be increased by 0.137 , assuming other independent variables have a fixed value.

\section{RESULTS AND DISCUSSION}

\subsection{The Effect of Usability Perceptions on the Use of E-learning}

Based on the results of hypothesis testing in chapter $\mathrm{IV}$, it can be explained that the usefulness perception has a significant positive effect on the use of elearning for undergraduate students of Accounting Education of 2015. This shows that the better usefulness perception of students towards elearning, the more often students use e-learning. Likewise, on the contrary, the lower the students' usefulness perception of e-learning, the lower the use of e-learning. 
Students who have a high usefulness perception will type themselves to believe that using e-learning will improve their performance. This means that students who think that e-learning brings many benefits, will often use e-learning. Students using e-learning will feel the benefits of e-learning which can be accessed easily by using the internet network any time without being limited by distance and time. Students also can study or review the materials any time because e-learning can store material in the form of a data base. This is in line with the concept of Technology Acceptance Modeling (TAM) proposed by Davis (1989) which stated that usefulness perception is one of the factors that influence a person to use a technology.

\subsection{The effect of perceived ease of use on the use of e-learning}

Based on the results of hypothesis testing in chapter IV, it can be explained that the ease of use perception has a significant positive effect on the use of elearning for undergraduate students in Accounting Education of 2015. This shows that the better the ease of use perception by students towards elearning, the higher the students who use e-learning. Likewise, on the contrary, the lower the ease of use perception by students towards e-learning, the lower the use of e-learning.

Pranidana (2011) believed that ease of use perception will reduce a person's time and energy in learning information technology. Students will use e-learning if the e-learning system is easy to be used and users do not need a lot of effort in using it. Students who have a high ease perception of elearning will tend to use e-learning more often. This is in line with the concept of the Technology Acceptance Model (TAM) put forward by Davis (1989) which stated that the ease of use perception is one of the factors in using technology.

\subsection{The Effect of Self Confidence on the Use of E-learning}

Based on the results of hypothesis testing in chapter IV, it can be explained that self-confidence has a significant positive effect on the use of e- learning for undergraduate students of Accounting Education of 2015. This shows that the higher the student's selfconfidence, the higher the use of e-learning by students. Conversely, the lower the student's selfconfidence, the less e-learning is used by students.
Students who have a high self-confidence will feel confident in themselves to be able to use technology well. Individuals with a higher level of selfconfidence rated themselves as being able to complete computational tasks that were given better without the support and assistance of others, than someone with a lower level of self-confidence (Dalcher and Shine, 2011, p. 446). High selfconfidence in individuals will lead to a higher level of interest and use of technology. The high level of self-confidence in students will further increase the use of e-learning itself. On the other hand, students with low self-confidence usually feel that they have not been able to use a technology properly. In addition, this person will solve problems independently either by using manual methods or by learning to use technology so that they can use them. Despite these students have low selfconfidence, they have a potential to use e-learning for learning media. The results of this study are in line with the research hypothesis which stated that there is a significant positive effect on selfconfidence on the use of e-learning.

\subsection{The Effect of Subjective Norms on the Use of E-learning}

Based on the hypothesis testing in chapter IV, it shows that subjective norms have a significant positive effect on the use of e-learning in undergraduate students of Accounting Education of 2015. That is, it shows that students will use elearning if the student has subjective norms or encouragement from someone who is trusted enough. Students who have high subjective norms will do something when other people or trusted sources say to them to do a certain thing. Meanwhile, students with low subjective norms tend not to do certain things.

Subjective norms related to external factors, in this case the influence of other people who are considered important, both the status of that person and the suggestions of those around them that can be taken into consideration by students in deciding to use elearning. Social referrals are in the form of good advice from the surrounding environment from lecturers and fellow students from people on campus. This affects students to use e-learning because it directly or indirectly provides a stimulus for students to use elearning. This is in accordance with the concept of planned behavior theory developed by Ajzen (1991) and Hamzah (2009) in Hidayati (2014) which stated that theory planned behavior is a theory discussing one's planned behavior in the utilization and use of money information system technology based on three things, one of which is subjective norms. The more individuals pay an attention that their social reference 
is more recommended to do something, the individual will tend to feel pressure to do the suggestion (Ajzen, 2006). It can be concluded that the greater the influence of other people around students, both lecturers and student friends in using e-learning, will make students feel confident about using e-learning. The results of this study are in line with the research hypothesis, stating that there is a significant effect of subjective norms on the use of e-learning in students of S1 Accounting Education.

\section{CONCLUSIONS}

Factors affecting the use of e-learning are based on the theory acceptance model (TAM), consisting of usefulness perception and ease of use perception, with added factors are self-confidence and subjective norms. The results of the study prove that usefulness perception, ease of use perception, selfconfidence, and subject matter norms have a significant positive effect on the use of e-learning in undergraduate students of Accounting Education of 2015. Based on the results of the study, the value of $\mathrm{R}$ square or the coefficient of determination shows that the effect of perceived usefulness, perceived ease of use, self-confidence, and subjective norms on the use of e-learning is only reached $56 \%$, then the remaining is $44 \%$, indicating other factors that influence use of e-learning. Not all the courses taken by students use e-learning facilities, so the results of the study are not in depth discussion.

Students are expected to give more positive responses to the direct or indirect socialization given by lecturers and the campus, especially regarding elearning that students can find out the advantages and disadvantages of e-learning, so it can be a consideration for students to use e-learning as an effective learning medium. The need for e-learning development is expected to develop e-learning by making more detailed features to be easier operated by users. For further research, the variables used in this study do not fully explain the factors that influence the use of e-learning. It is hoped that it can pay more attention to other factors that affect the use of e-learning, both those that come from within oneself or internal factors or from the environment or external factors. In addition, the respondents used can be expanded not just in one scope. Moreover, data collection techniques can be improved by using interviews and observations so that the data obtained can be more detailed.

\section{REFERENCES}

[1] Ajzen, I. (2006). Constructing theory of planned behavior questionnaire. Retrieved from https://people.umass.edu/ aizen/pdf/tpb.measu rement.pdf.

[2] Aristian, M., Setyohadi, D. B., \& Sinaga, B. L. (March, 2016). Faktor yang mempengaruhi niat penggunaan e-learning oleh mahasiswa pada Universitas Atma Jaya Yogyakarta. Seminar Nasional Teknologi Informasi dan Komunikasi 2016, Sentika: Yogyakarta.

[3] Boateng, R., Mbrokoh, A. S., Boateng, L., Senyo, P. K., \& Ansong, E. (2016). Determinant of e-learning adoption in among student of developing countries. International Journal of Information and Learning Technology, 33(4), 248-262. Retrieved from http://www.emeraldinsight.com/2046-

\section{X.htm}

[4] Dalcher, I., \& Shine, J. (2011). Extending the new technology acceptance model to measure the end user information systems satisfaction in a mandatory environment: A bank's treasury. Technolgy Analysis \& Strategic Management, 15(4), 441-455.

[5] Davis, F. D. (1989). Perceived usefulness, perceived ease of use, and user acceptance of information technology. Management Information System Quarterly, 13(3), 319-339. Retrieved from http://www.cba.hawaii.edu/chismar/ITM704/D avisTAM1989.pdf.

[6] Hidayati, H., \& Najemi, C. (2014). Upaya peningkatan minat dan prestasi belajar IPA siswa kelas VIII SMP Negeri 12 Yogyakarta tahun pelajaran 2012/2013 melalui model pemebelajaran konstruktivisme. Jurnal Ilmiah Pendidikan IPA, 1(1).

[7] Jogiyanto. (2007). Sistem Informasi Keprilakuan. Yogyakarta: Andi Offset. 
[8] Priyatno, D. (2009). 5 Jam belajar olah Data SPSS 17, J, Widyatmoko [eds]. Yogyakarta: Andi Offset.

[9] Raaij, E. M., \& Schepers, J. J. L. (2008). The acceptance and use of a virtual learning environment in China. Computers dan education, 50(3), 838-852.

[10] Sekaran, U. (2015). Research methods for business metodologi penelitian untuk bisnis. Jakarta: Salemba Empat.

[11] Tarhini, A., \& El-Masri, M. (2017). Factors affecting the adoption of e-learning system in Qatar and USA: Extending the unified theory of acceptance and use of technology 2 (UTAUT2). Educational Technology Research and Development, 65(3), 1-21.
[12] Venkatesh, V., Morris, M. G., \& Ackerman, P. L. (2000). A longitudinal field investigation of gender differences in individual technology adoption decision-making processes. Organizational Behaviour and Human Decision Processes, 83(1), 33-60.

[13] Wijaya, T. (2013). Metodologi penelitian ekonomi dan bisnis: Teori dan praktik. Yogyakarta: Graha Ilmu.

[14] Yunasti., Ika, F., \& Baridwan, Z. (2013). Penerimaan individu terhadap sistem informasi berbasis computer: Pendekatan modified technology acceptance model (TAM). Jurnal Ilmiah Mahasiswa FEB, 2(1). 